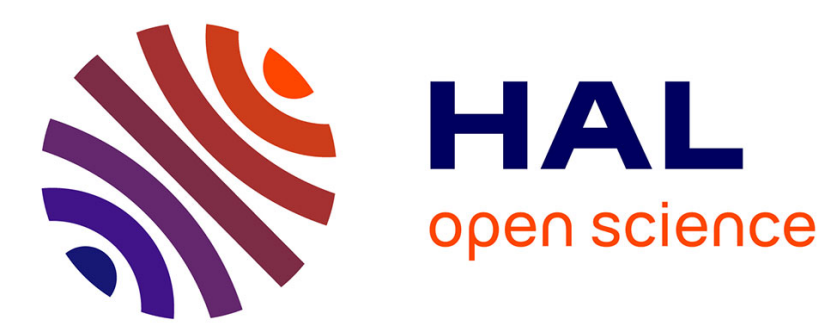

\title{
Alexander Vaiserman (ed.): Early life origins of ageing and longevity
}

Eric Le Bourg

\section{To cite this version:}

Eric Le Bourg. Alexander Vaiserman (ed.): Early life origins of ageing and longevity. Biogerontology, 2020, 21, pp.131-132. 10.1007/s10522-019-09833-2 . hal-02321851

\section{HAL Id: hal-02321851 \\ https://hal.science/hal-02321851}

Submitted on 6 May 2020

HAL is a multi-disciplinary open access archive for the deposit and dissemination of scientific research documents, whether they are published or not. The documents may come from teaching and research institutions in France or abroad, or from public or private research centers.
L'archive ouverte pluridisciplinaire HAL, est destinée au dépôt et à la diffusion de documents scientifiques de niveau recherche, publiés ou non, émanant des établissements d'enseignement et de recherche français ou étrangers, des laboratoires publics ou privés. 


\section{Book review}

3 Early Life Origins of Ageing and Longevity: Alexander Vaiserman

4 (editor)

5 Springer, Dordrecht, 2019, 310 pp, hard back, ISBN 978-3-030-24957-1

$7 \quad$ Éric Le Bourg

9 E. Le Bourg () ) Centre de Recherches sur la Cognition Animale (CRCA), Centre de Biologie 10 Intégrative (CBI Toulouse), Université de Toulouse, CNRS, UPS, Toulouse, France

11 e-mail: eric.le-bourg@univ-tlse3.fr

The book series Healthy Ageing and Longevity has published a new volume (\# 9) dealing with the early-life origins of ageing and longevity. However, this book is not only concerned with ageing but more generally with adult health. This is an important topic and there are now many studies showing that improving health, particularly at old age, requires looking into what happened since the conception and even to what happened to the parents. As a fictitious example, one of the characters of the 1890 novel La Bête humaine, written by the French writer Émile Zola, was a man suffering from unavoidable outbreaks of violence because of alcoholism of his mother. The Dutch famine of the winter 1944-1945 is a clear example when hunger of the mother had serious consequences at old age for the foetus developing at that time. Thus, publishing this collective book was a good idea but it is really unfortunate that it contains many typos or grammatical errors, as for instance in the first chapter. It becomes ridiculous when this chapter is dealing with the 1966-1968 Finnish famine (page 8), rather than the 1866-1868 one! While one can blame the authors for not reading carefully their own proofs, some mistakes could be avoided if the publisher had provided copy-editing services to the authors, especially to those for whom English is not their first language. Furthermore, the size and resolution of figures are another issue. Consider for instance Fig. 13.3 showing "dots" and "circles": this is hardly possible to see them, even under binocular vision (I have tried)! The issue of providing readers with best-quality books should be treated by the publisher in future books of this series Healthy Ageing and Longevity. The payment made by customers is always of the "high" quality, books should be too. 
The two first chapters delineate what are the developmental origins of adult health and disease $(\mathrm{DOHaD})$ and why early life events, including in utero, can have major consequences in the adult and even at old age. Chapters 3-6 focus on early-life programming of ageing by modulating the fate of offspring, either by famine, intra-uterine growth restriction, or obesity of the mother, showing particularly that the effects can be trans-generational, inducing, for instance, a vicious cycle of obesity in humans, with obese mothers having too heavy babies becoming obese and giving birth to too heavy babies. A caveat here is that obesity of mothers is more probable if they have a low socioeconomic status and, thus, a policy trying to reduce social inequalities would also have positive consequences on public health (see Chapter 15 for a discussion).

Unfortunately, it is not the end of the story, because, beyond nutrition, social adversity, maternal depression, and other events during the prenatal period may impair offspring (Chapter 7). Chapters 8-9 are concerned with osteoporosis and the role of nutrition to avoid life-long health issues. The issue is that, sometimes, these different chapters may provide a similar information, for instance on epigenetics (for a general review, see Chapter 14).

The part three of the book is dealing with epidemiology. Chapters 10 and 12 describe the effects of prenatal undernutrition and famine, while Chapter 11 focuses on the role of obesity. All the previous chapters were mainly concerned with early nutrition, but Chapter 13 introduces a new topic, by wondering whether the resilience of 18 year-old men, i.e. the ability to cope with severe adversity, is linked with parental lifespan. One may think that early experience is not limited to nutrition but also to all experiences in early life.

I was surprised that the issue of telomeres was not considered in this book, except very briefly on page 200. One can agree or disagree with the hypothesis that the length of telomeres has an effect on lifespan and ageing, but there are now many papers that try to clarify the issue. As the length of telomeres has also been considered as a marker of stress, even in early life, I fail to understand why this topic was neglected.

The last chapter argues that without a policy fighting social inequalities, and not only directed towards pregnant women, there is only a little hope to avoid life-long consequences of early life stress at the population level. This is a right conclusion but the worrying reality is that social inequalities are increasing in many countries. The authors argue that "the lack of action on social policy may well be due to the lack of awareness on DOHaD among policymakers" (page 299), but it could be that, like everybody, most of policy makers know that poor people live for a shorter time than wealthy ones and that children of poor people are more at risk to be poor at adult and old ages, than those of wealthy parents.

This book compiles many results on the effects of early life on ageing and health at adult and 
68 medicine, nutrition, and so on, this book is particularly helpful for biogerontologists, but also for 69 nutritionists and other physicians. Health at old age can be traced up to conception, and even before 70 it, as shown by trans-generational effects, and this is the main conclusion when reading this useful 71 book. 